\title{
A Review About Probiotic Foods: Kefir, Kimchi and Kombucha
}

\section{Felix ASH $^{*}$}

Department of Food Processing and Engineering, Karunya University, Coimbatore, India

\begin{abstract}
This article summaries about the few selected probiotic foods like Kefir, Kimchi and Kombucha. These are all the food products which contain high probiotic benefits while comparing with other normal intake. Author has explained how to prepare these probiotic foods and its nutritional values and shown about the product with collected diagrams and information.
\end{abstract}

Keywords: Probiotic foods; Kefir; Kimchi; Kombucha

Abbreviations: g: Gram; hrs: Hours; mg: Milligram; ml: Milliliter; RDA: Recommended Daily Allowances

\section{Introduction}

Probiotics it becomes popular in the early 20th century by Nobel recipient Élie Metchnikoff. Later lot of researchers found that probiotics are essential and useful to human as well as animal because it used as a predictor for most of the common and serious diseases like Allergies, Antibiotic-associated diarrhea (AAD), Bacterial vaginosis, Blood pressure, Central nervous system function and disorders, Cholesterol, Diarrhea, Eczema, Immune function and infections, Inflammation, Inflammatory bowel disease, Irritable bowel syndrome, Lactose intolerance, Necrotizing enterocolitis, Urinary tract, etc. to prevent or cure the natural occurring probiotic bacteria like Bifidobacterium, Lactobacillus genera, B. longum, B. breve, B. infantis, L. helveticus, $L$. rhamnosus, $L$. plantarum, and $L$. casei are very much active needed species. Consuming probiotic has to be mandatory in human daily intake because prevention is better than cure.

\section{Kefir}

Kefir is a fermented milk product by blending the milk and kefir grains. Kefir also called as kephir, kefir and búlgaros.

Ingredients: Milk (cow or goat) Kefir grains, Non-metal vessel, Rubber band and Cheese cloth or Paper towel.

Procedure to prepare: Add 1 cup of milk in the non-metal vessel along with 1 table spoon of kefir grains (Figure 1A) and cover the vessel with cheese cloth or paper towel using rubber band, then store the blended product (Figure 1B) in order to ferment in room temperature between $60^{\circ} \mathrm{F}$ to $90^{\circ} \mathrm{F}$ for $24 \mathrm{hrs}$, kefir (Figure 1C) is ready to consume.

Benefits: Kefir grains contain more than 30 strains of beneficial bacteria and yeasts [1-3] along with Essential nutrition's (Table 1).

Probiotics: Bifidobacterium bifidum, Lactobacillus acidophilus, Lactobacillus delbrueckii subsp, Lactobacillus delbrueckii subsp. Bulgaricus, Lactobacillus helveticus, Lactobacillus kefiranofaciens, Lactococcus lactis, Leuconostoc, Streptococcus thermophilus.

\section{Kimchi}

Kimchi is a fermented dish from Korean people made up of variety of seasonings and vegetables. Also, called as kimchee or gimchi.

Ingredients: Plus, Salt, Carrot, Water, Cabbage, Scallions, Ginger, Garlic, Anchovy fish sauce or Brine shrimp sauce, Pepper, Radish, Sugar.

Procedure to prepare: Wash the vessel properly dissolve $42.9 \mathrm{~g}$ of salt in water and keep aside take a large size bowl add $908 \mathrm{~g}$ of Chinese cabbage Napa (Figure 1D) and pour the brine over it. Now weigh the cabbage down with a plate wait for $12 \mathrm{hr}$ then drain the brine and add remaining ingredients 1 normal sized carrot chopped in to shape of French fries, 6 scallions chopped length of 2 inch, $7 \mathrm{~g}$ of minced fresh ginger, $7 \mathrm{~g}$ of minced garlic, $43 \mathrm{~g}$ of brine shrimp sauce (Figure 2A) or anchovy fish sauce, 1/4 cup of Korean ground dried hot pepper, 1 cup of shredded Korean radish, $15 \mathrm{~g}$ of sugar along with $15 \mathrm{~g}$ of salt. Then pack it in a glass jar Let the kimchi ferment in a cool place, at a temperature no higher than $68^{\circ} \mathrm{F}\left(20^{\circ} \mathrm{C}\right)$, for 3 to 6 days. Allow to ferment until the kimchi (Figure $2 \mathrm{~B}$ ) is as sour as you like.

Benefits: Kimchi is rich in vitamins $\mathrm{A}$ and $\mathrm{C}$ and due to its fermentation process is also rich in beneficial gut-boosting lactobacilli bacteria [4-6]. It has potent antioxidative and immune-stimulating activities along with Essential nutrition's (Table 2).

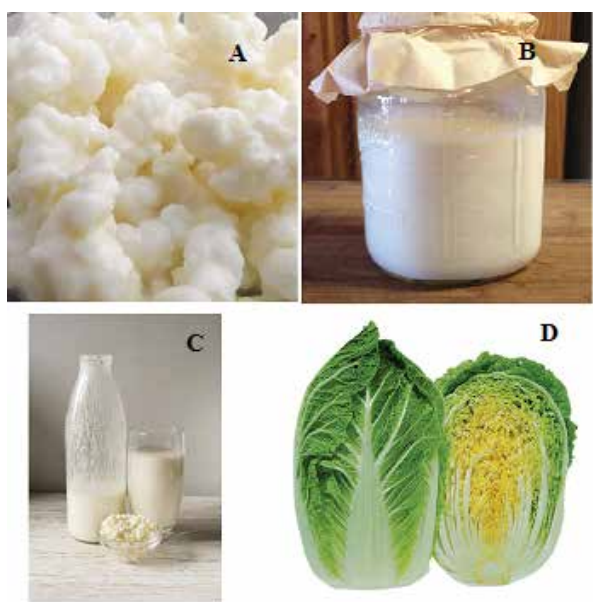

Figure 1: (A) Kefir grains (B) Blended kefir in non-metallic vessel (C) Kefir (D) Chinese cabbage Napa.

*Corresponding author: Felix Samuel HA, B. Tech, Department of Food Processing and Engineering, Karunya University, Coimbatore, India, Tel: +91- 888 3888 016; E-mail: felixingodd@gmail.com

Received October 19, 2016; Accepted November 08, 2016; Published November 15,2016

Citation: Felix ASH (2016) A Review About Probiotic Foods: Kefir, Kimchi and Kombucha. J Food Process Technol 7: 636. doi: 10.4172/2157-7110.1000636

Copyright: ( 2016 Felix ASH. This is an open-access article distributed under the terms of the Creative Commons Attribution License, which permits unrestricted use, distribution, and reproduction in any medium, provided the original author and source are credited. 
Citation: Felix ASH (2016) A Review About Probiotic Foods: Kefir, Kimchi and Kombucha. J Food Process Technol 7: 636. doi: 10.4172/21577110.1000636

Page 2 of 2

\begin{tabular}{|c|c|c|}
\hline \multirow{2}{*}{ S.no. } & \multicolumn{2}{|c|}{ Estimated for $\mathbf{1 7 5} \mathbf{~ m l}$} \\
\cline { 2 - 3 } & Substance & Level \\
\hline 1 & Protein & $6 \mathrm{~g}$ \\
\hline 2 & Calcium & $20 \%$ of the RDA \\
\hline 3 & Phosphorus & $20 \%$ of the RDA \\
\hline 4 & Vitamin B12 & $14 \%$ of the RDA \\
\hline 5 & Riboflavin (B2) & $19 \%$ of the RDA \\
\hline 6 & Magnesium & $5 \%$ of the RDA \\
\hline
\end{tabular}

Table 1: Nutrition values of Kefir.
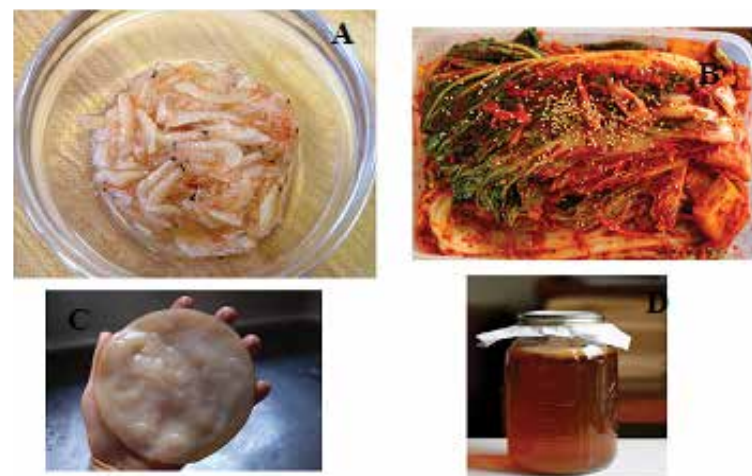

Figure 2: (A) Brine shrimp sauce (B) Kimchi (C) Scoby (D) Kombucha.

\begin{tabular}{|c|c|c|}
\hline \multirow{2}{*}{ S.no. } & \multicolumn{2}{|c|}{ Estimated for $\mathbf{1 0 0} \mathbf{~ g}$} \\
\cline { 2 - 3 } & Substance & Level \\
\hline 1 & Calories & 33 \\
\hline 2 & Sodium & $899 \mathrm{mg}$ \\
\hline 3 & Carbohydrates & $6 \mathrm{~g}$ \\
\hline 4 & Protein & $2 \mathrm{~g}$ \\
\hline 5 & Vitamin A & $50 \%$ of the RDA \\
\hline 6 & Vitamin C & $53 \%$ of the RDA \\
\hline 7 & Fiber & $3 \mathrm{~g}$ \\
\hline 8 & Sugar & $2 \mathrm{~g}$ \\
\hline
\end{tabular}

Table 2: Nutrition values of Kimchi.

\begin{tabular}{|c|c|c|}
\hline \multirow{2}{*}{ S.no. } & \multicolumn{2}{|c|}{ Estimated for $\mathbf{2 5 0} \mathbf{~ m l}$} \\
\cline { 2 - 3 } & substance & Level \\
\hline 1 & Calories & 30 \\
\hline 2 & Sodium & $30 \mathrm{mg}$ \\
\hline 3 & Carbohydrates & $5 \mathrm{~g}$ \\
\hline 4 & Potassium & $88 \mathrm{mg}$ \\
\hline 5 & Sugars & $5 \mathrm{~g}$ \\
\hline
\end{tabular}

Table 3: Nutrition values of Kombucha.

Probiotics: Lactic acid bacteria: Lactobacillus kimchii and other lactic acid bacteria.

\section{Kombucha}

Kombucha is fermented tea dated back 1900 's used by different kind of people like Chinese, Japanese, Russians, Germans, Americans, etc.
Ingredients: Water, Sugar, Tea bags (Black or Green), Scoby kombucha (unpasteurized).

Optional flavoring: Chopped fruit, Fruit juice, Hibiscus, Honey, Herbs or Spices.

Procedure to prepare: To prepare 1 gallon of kombucha dissolve 1 cup of sugar and 8 tea bags in 31/2 quarts of boiling water and cool it. Once it get cooled remove the tea bags then pour the solution equally in 2 separate glass jars of each 1 gallon. Take 2 scobys (Figure 2C) slide in both the jars gently along with optional flavoring and cover the lid tightly with woven cloth. Store it in room temperature for 7 to 10 days to ferment. After a week Kombucha tea (Figure 2D) is ready.

Benefits: Researches have been found that Kombucha may reduce heart disease risk, help to manage type- 2 diabetes, protect against cancer [7-9] and contains essential nutrition's (Table 3).

Probiotics: Kombucha contains over 50 different kinds of probiotics, organic enzymes, amino acids and vitamins.

\section{Conclusion}

Kefir, Kimchi and Kombucha are the healthy food products which has more health benefits along with probiotics. It will give good outcome when it consumed in early morning in empty stomach after taking a glass of water. Simple food products will keep a doctor away from you. 'Prevention is better than Cure'.

\section{References}

1. Fijan S (2016) Influence of the growth of pseudomonas aeruginosa in milk fermented by multispecies probiotics and kefir microbiota. J Prob Health 4: 136

2. Soleimanifard M, Alami M, Chegeni FK, Najafian G, Mahoonak AS, etal. (2015) Production of kefiran in kefir grains and its effects on the rheological properties low protein wheat dough and quality of France bulky bread. Adv Crop Sci Tech 3: 190.

3. Ino M, Matsukawa M, Yamaoka Y, Hanada K, Fujii C (2014) Prophylactic effects of kefir-fermented milk on constipation among mentally and physically handicapped persons. J Prob Health 3: 126.

4. Kim JY, Choi EY, Hong YH, Song YO, Han JS, et al. (2016) Changes in Korean adult females' intestinal microbiota resulting from kimchi intake. J Nutr Food Sci 6: 486

5. Kim JH, Ryu JD, Song YO (2002) The effect of kimchi intake on free radical production and the inhibition of oxidation in young adults and the elderly people. Korean J Community Nutr 7: 257-265.

6. In HC, Jeong SN, Ji-Sook H, Hyun JK, Eung-Soo H, et al. (2013) Kimchi, a fermented vegetable, improves serum lipid profiles in healthy young adults: Randomized clinical trial. J Medicinal Food 16: 223-229.

7. Santos RJ Jr, Batista RA, Rodrigues SA, Filho LX, Lima AS (2009) Antimicrobia activity of broth fermented with kombucha colonies. J Microbial Biochem Technol 1: 72-78.

8. Greenwalt CJ, Steinkraus KH, Ledford RA (2000) Kombucha, the fermented tea: Microbiology, composition, and claimed health effects. J Food Protect 7 : 855-986.

9. Natasha CD (2015) Benefits of kombucha: The many benefits of kombucha 